\title{
Change in root apical protein and peroxidase activity in response to aluminum in tolerant and sensitive maize inbred lines
}

\author{
Isabel Regina Prazeres de Souza1*, Vera Maria Carvalho Alves', Sidney Netto Parentoni1, \\ Antônio Carlos de Oliveira1, Flávia França Teixeira1, Jennifer Wilson MacAdam² and \\ Antônio Álvaro Corsetii Purcino1
}

1Empresa Brasileira de Pesquisa Agropecuária - CNPMS, CP 151, 35701-970, Sete Lagoas, MG, Brasil; ${ }^{2}$ Department of Plants, Soils, and Biometeorology, Utah State University, Logan, UT 84322-4820,USA; *Corresponding author: isabel@cnpms.embrapa.br Received: 22/02/2002, Accepted: 29/08/2002

The effects of a short-term ( $80 \mathrm{~min}$ ) exposure to $222 \mu \mathrm{M}$ aluminum ( $\mathrm{Al}$ ) on the protein content and expression and on peroxidase activity and isoenzymes in the primary root of maize were evaluated. Two inbred lines differing in their level of tolerance to Al were used: Cateto 237 (tolerant) and L36 (sensitive). The apical $20 \mathrm{~mm}$ of the primary root was divided into 2-mm-long segments that were analyzed for total protein content and peroxidase activity. These results demonstrate that the total protein content along the root apex was not affected by $\mathrm{Al}$ in the tolerant inbred line, but decreased in the sensitive line. In the apical $2 \mathrm{~mm}$ of the root of the sensitive line, the expression of low molecular weight proteins (43 $\mathrm{kDa}$ or smaller) was decreased. Expression of low molecular proteins increased in the tolerant inbred line, even though total protein content did not increase. This suggests that some of these proteins could play a role in metal tolerance, perhaps as binding peptides. While the peroxidase activity of the tolerant inbred line did not change with exposure to Al, peroxidase activity in the apical $6 \mathrm{~mm}$ of the root of the sensitive line decreased. The tolerant inbred line constitutively expressed more anionic peroxidase isoforms. These results demonstrate that maintenance of protein expression may be an important component of the plant's resistance to Al stress, and that resistance to $\mathrm{Al}$ stress is associated with the higher expression of anionic peroxidase isoforms.

Key words: aluminum toxicity, maize, peroxidase isoforms, root growth.

\begin{abstract}
Alterações no teor protéico e na atividade da peroxidase em resposta ao alumínio em ápice de raiz de linhagens de milho tolerante e sensível: $\mathrm{O}$ teor protéico, a expressão e a atividade de isoenzimas da peroxidase foram avaliados em ápices de raiz primária de plântulas de milho expostas a $222 \mu \mathrm{M}$ de alumínio (Al) por 80 minutos. Duas linhagens com tolerância diferencial ao Al foram utilizadas: Cateto 237 (tolerante) e L36 (sensível). Os $20 \mathrm{~mm}$ apicais da raiz primária foram segmentados em intervalos de $2 \mathrm{~mm}$ e analisados para teor protéico e atividade da peroxidase. Os resultados demonstraram que o teor protéico, ao longo do ápice da raiz da linhagem tolerante, não foi afetado pelo Al, mas decresceu na linhagem sensível. O decréscimo na expressão de proteínas, verificado nos $2 \mathrm{~mm}$ apicais da raiz da linhagem sensível, foi devido, principalmente, às proteínas de baixo peso molecular, aproximadamente $43 \mathrm{KDa}$ ou menor. A expressão de quase todas essas proteínas aumentou na linhagem tolerante, embora o teor protéico total não tenha sido alterado, sugerindo que algumas dessas proteínas possam ter um papel importante na tolerância das plantas aos metais, talvez como peptídeos ligantes. Enquanto a atividade da peroxidase na linhagem tolerante não alterou com a exposição ao Al, esta atividade decresceu ao longo dos $6 \mathrm{~mm}$ apicais da raiz na linhagem sensível. Mais isoformas aniônicas foram expressas constitutivamente na linhagem tolerante, sem, contudo, apresentar alterações qualitativas em resposta ao Al. Os resultados demonstraram que a manutenção da expressão protéica pode ser um componente importante da tolerância das plantas ao $\mathrm{Al}$, estando a resistência associada à expressão constitutiva de isoformas aniônicas da peroxidase.
\end{abstract}

Palavras-chave: crescimento radicular, milho, isoformas de peroxidase, toxicidade do alumínio. 


\section{INTRODUCTION}

Aluminum (Al) toxicity is the major growth-limiting factor for crop cultivation on acid soils (Foy, 1988), and crops grown on tropical and subtropical soils are mainly affected by this condition (Clark, 1982). Therefore, the development of Al-tolerant maize cultivars may help improve food production in developing countries.

Several lines of evidence have demonstrated that the root apex is the primary site of Al-induced root growth inhibition (Bennet and Breen, 1991, Ryan et al., 1993). It suggests that research on Al toxicity and resistance mechanisms should be directed to Al interactions within the root apex. The most frequently measured effect of Al toxicity is inhibition of root growth, but it is reasonable to assume that a number of physiological and biochemical processes in the plant cell have been affected before growth inhibition occurs (Rengel, 1996). It is generally difficult to separate primary responses related to inhibition of root growth from secondary responses that arise as the consequence of a damaged root system. Changes in enzyme activities and metabolite pools in response to stress are particularly useful in providing an early detection of primary alterations in plants. Several genes have been found to be up-regulated upon exposure to Al, and these include peroxidases (Ezaki et al., 1996; Hamel et al., 1998). In tobacco cells, activation or repression of some peroxidase isoenzymes were observed after Al treatment, suggesting that these isoenzymes have some function in Al stress (Ezaki et al., 1996), and in transgenic arabidopsis, expression of a peroxidase gene conferred a degree of resistance to Al (Ezaki et al., 2000). Peroxidases play an important role in plant metabolism and physiology, and are involved in the responses of plants to infectious and abiotic stress stimuli (Gaspar et al., 1985). Among the plant defense responses involving peroxidases are lignification (Walter, 1992), cross-linking of cell wall components (Bradley et al., 1992), suberization and wound healing (Sherf et al., 1993).

Induction of new proteins occurs in plants in response to a wide range of physical and environmental stress treatments (Ho and Sachs, 1989). Many plant species possess low molecular weight metal binding proteins that are induced by treatment with a variety of metals (specially $\mathrm{Cd}, \mathrm{Zn}, \mathrm{Cu}$ and $\mathrm{Pb}$ ) suggesting the possibility that $\mathrm{Al}$ is detoxified by formation of stable metal-protein complexes (Taylor, 1991). The gene encoding the arabdopsis blue copper-binding protein conferred Al resistance in yeast cells (Ezaki et al., 2000). Although several toxic effects of $\mathrm{Al}$ on plant growth have been proposed, the mechanism of Al toxicity is still to be clarified.

The aim of the research presented here was to investigate the effect of $\mathrm{Al}$ on protein content and expression, and peroxidase activity and isoenzymes along the main root apex of two maize inbred lines, Cateto 237 (tolerant) and L 36 (sensitive) differing in tolerance to $\mathrm{Al}$ toxicity.

\section{MATERIAL AND METHODS}

Plant material: Seeds of the Al-tolerant Cateto 237 and Al-sensitive L36 maize inbred lines were pre-germinated for 7 days on germination paper then transferred to an aerated nutrient solution as described by Magnavaca (1982). The volume of the nutrient solution was maintained by daily additions of freshly prepared solution. Five days after transfer, 32 seedlings of each inbred line were submitted to a short-term ( $80 \mathrm{~min}) \mathrm{Al}$ stress and 32 seedlings of each line were kept as controls. This shortterm Al stress was used trying to verify the primary and not secondary plant response to Al. Stress was imposed by adding $222 \mu \mathrm{M} \mathrm{AlK}\left(\mathrm{SO}_{4}\right)_{2} \cdot 12 \mathrm{H}_{2} \mathrm{O}$ to the nutrient solution, with the $\mathrm{pH}$ lowered to 4.0 by addition of $1 \mathrm{~N}$ $\mathrm{HCl}$. The $222 \mu \mathrm{M}$ is the dose previously established to select maize susceptible and resistant to Al (Magnavaca, 1982). Control plants had the same nutrient solution and $\mathrm{pH}$, except Al. The experiment was carried out in a greenhouse with day/night temperatures of 35/26 $\mathrm{\circ} \pm 5$ ${ }^{\circ} \mathrm{C}$ and relative humidity of $70 \% \pm 5 \%$. Each treatment was replicated four times.

Protein extraction and SDS-PAGE: The apical $20 \mathrm{~mm}$ of the primary root of seedlings of each treatment was collected and segmented at 2-mm intervals, with the temperature maintained at $4{ }^{\circ} \mathrm{C}$. Segments from each section were ground in liquid nitrogen to a fine powder and extracted in three volumes of $50 \mathrm{mM}$ phosphate buffer, $\mathrm{pH}$ 6.0, containing $1 \mathrm{mM}$ phenylmethylsulfonyl fluoride (PMSF) and $1.5 \%$ polyvinylpolypyrrolidone $(\mathrm{w} / \mathrm{v})$. The homogenate was centrifuged at $14,000 g_{\mathrm{n}}$ at $4{ }^{\circ} \mathrm{C}$ for $30 \mathrm{~min}$ and the supernatant used for protein estimation and peroxidase assay. Soluble protein content was determined using the Bradford (1976) microtiter plate protocol (Bio-Rad). 
Twenty-five $\mu \mathrm{g}$ soluble protein from the apical $2 \mathrm{~mm}$ of the root was separated by SDS-PAGE using the Laemmli (1970) system on a $12.5 \%$ running gel for $90 \mathrm{~min}$ at $100 \mathrm{~V}$. Bands were visualized by staining with silver nitrate (Blum et al., 1987). Molecular weight markers of pre-stained 14.3 to $200 \mathrm{kDa}$ protein standards (Gibco BRL) were run in an adjacent well.

Peroxidase assay: Peroxidase activity was assayed at 30 ${ }^{\circ} \mathrm{C}$ as described by Souza and MacAdam (1998) using guaiacol as the substrate. Total soluble peroxidase activity and soluble protein content are reported on a tissue fresh weight basis. The reaction was initiated by addition of 10 $\mu \mathrm{l}$ of soluble protein to the reaction mixture, and the increase in absorption was measured at $470 \mathrm{~nm}$.

Isoelectric focusing: Four $\mu \mathrm{l}$ of supernatant, approximately $10 \mu \mathrm{g}$ soluble protein, from each sample along the primary root apex was loaded onto a $1 \%(\mathrm{w} / \mathrm{v})$ isogel agarose (Amersham Pharmacia Biotech) with $6.7 \%$ ampholytes $(\mathrm{v} / \mathrm{v})$ in the $\mathrm{pH}$ range 3 to 10 (Amersham Pharmacia Biotech). Gels were cast onto Gelbond using a 125 x 260 x $1 \mathrm{~mm}$ mould (Amersham Pharmacia Biotech) and were run using a Multiphor II electrophoresis unit (Amersham Pharmacia Biotech). Prefocusing was carried out for 20 min at $1200 \mathrm{~V}$ and $1 \mathrm{~W}$, and the gel was focused for $2 \mathrm{~h}$ at $1200 \mathrm{~V}$ and $4 \mathrm{~W}$ at $10{ }^{\circ} \mathrm{C}$. After electrophoresis the gel was stained for peroxidase activity using the $\rho$-phenylenediamine-pyrocatechol (PPD-PC) protocol (Imberty et al., 1984). To determine the isoelectric point ( $\mathrm{pI}$ ), markers ranging from 4.45 to 9.6 (Bio-Rad) were run on each gel.

Statistical analysis: Analysis of variance was carried out using the GLM procedure of the Statistical Analysis System Computer Package (SAS Institute, Inc.,1993).

\section{RESULTS AND DISCUSSION}

Aluminum caused a significant decrease in the protein content of the root in the three segments between 4 and 10 $\mathrm{mm}$ from the root apex of the L36 (sensitive) line (figure 1A), but there was no change in the Cateto 237 (tolerant) line (figure 1B). Protein content was highest at the root tip (0-2 $\mathrm{mm})$ in both lines, where cell division occurs, and of the two lines, it was higher for the Al-sensitive L36 line.

Untreated (-Al) primary roots of the L36 seedlings were longer and thinner, had more lateral roots and hairs, and had a higher growth rate of $1 \pm 0.18 \mathrm{~mm} \cdot \mathrm{h}^{-1}$ compared to a growth rate of $0.8 \pm 0.14 \mathrm{~mm} \cdot \mathrm{h}^{-1}$ for untreated Cateto 237 roots.

Protein profiles from the apical $2 \mathrm{~mm}$ of the two inbred lines differed in response to Al. Protein expression was inhibited in Al-sensitive L36 but expression of some of the same proteins was stimulated in Al-tolerant Cateto 237 (figure 2). The majority of the difference in expression was in proteins with molecular weight less than 43 kDa. Rincón and Gonzales (1991) also found that most changes caused by Al, mainly the inhibition of protein synthesis, occurred in the low molecular weight proteins in wheat. During a long-term Al treatment in wheat, Picton et al. (1991) demonstrated changes that included repression of protein synthesis, but across a broader molecular weight range.
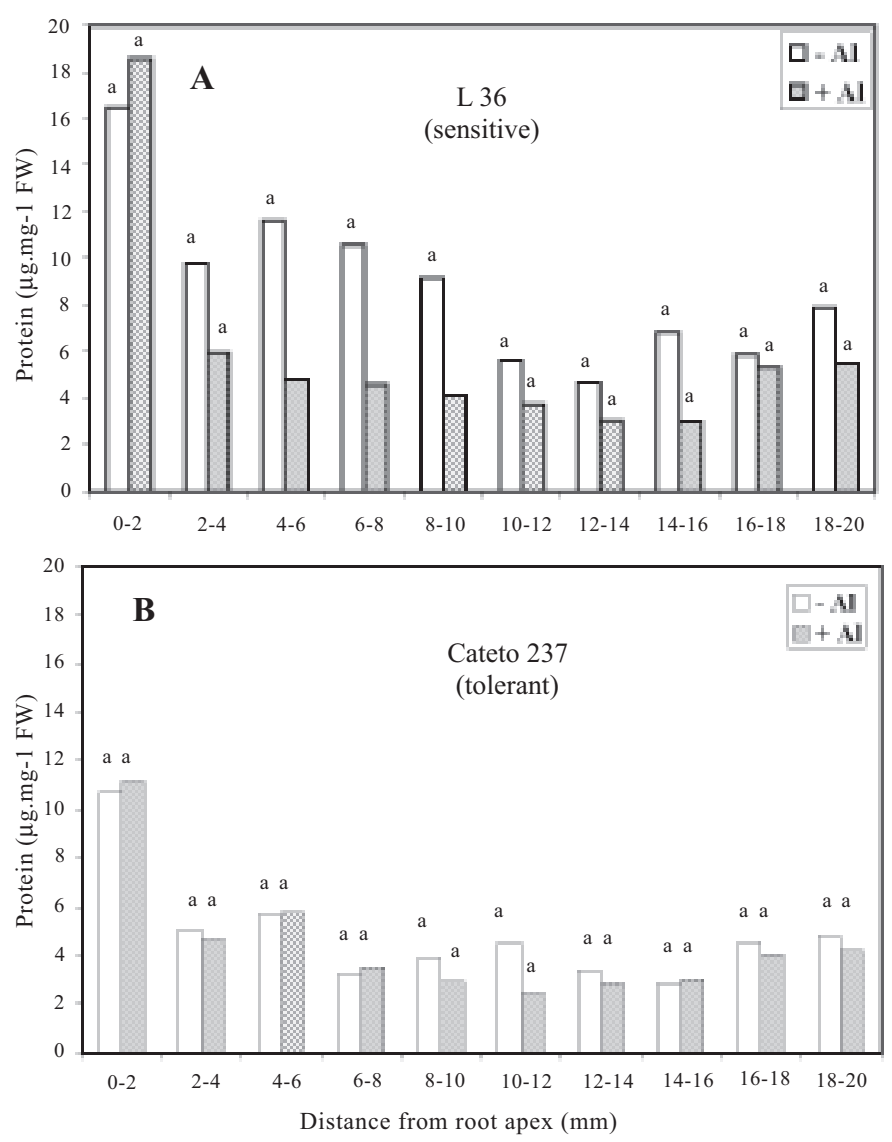

Figure 1. Mean soluble protein content along the apical $20 \mathrm{~mm}$ of the main root of the inbred lines L36 (sensitive) and Cateto 237 (tolerant) submitted to a shortterm (80 min) without (-Al) or with $222 \mu \mathrm{M}$ aluminum stress $(+\mathrm{Al})$. Bars, within the same region, followed by the same letter do not differ significantly according to Tukey's test at the probability level $p \leq 0.05$ 


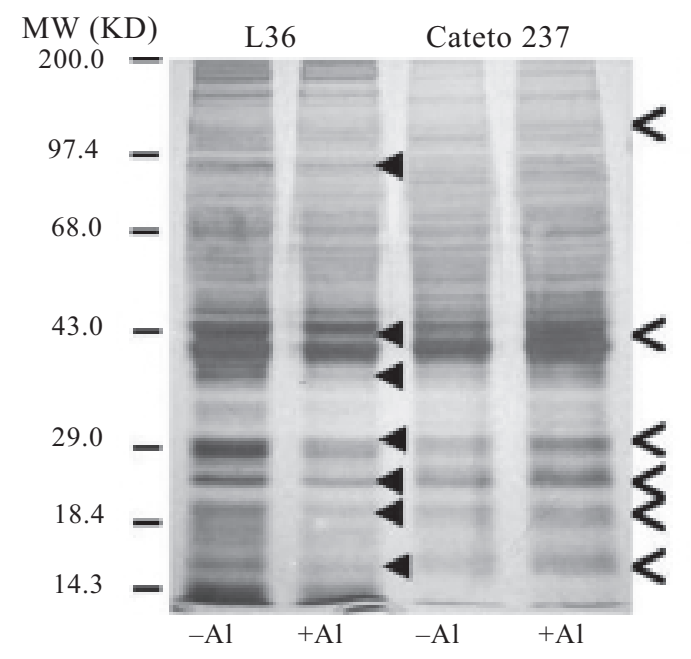

Figure 2. SDS-PAGE profiles of the proteins expressed in the first apical $2 \mathrm{~mm}$ of the root of the inbred lines L36 (sensitive) and cateto 237 (tolerant) submitted to a short-term $(80 \mathrm{~min})$ without $(-\mathrm{Al})$ or with $222 \mu \mathrm{M}$ aluminum stress $(+\mathrm{Al})$. Proteins were separated on a $12 \%$ polyacrilamide gel and the gels were stained with silver nitrate. Molecular weight markers are indicated on the left. Twenty-five $\mu \mathrm{g}$ of protein were loaded per lane. Arrows show proteins that had their expression decreased ( $\triangleleft)$ or stimulated $(<)$ by aluminum.

In the tolerant inbred line, Cateto 237, $\mathrm{Al}$ caused an increase in expression of low molecular weight proteins, suggesting their role as binding peptides in metal tolerance (Kochian, 1995). Considering that the tolerant inbred line was capable of increasing the expression of some proteins that were already present and that were inhibited by $\mathrm{Al}$ in the sensitive inbred line, tolerance may be due to these particular constitutive proteins.

In figures $3 \mathrm{~A}$ and $3 \mathrm{~B}$ it can be seen that peroxidase activity in the apical $6 \mathrm{~mm}$ of the primary root of L36 was reduced by $\mathrm{Al}$ exposure. This region includes the meristem and at least part of the elongation zone. In squash, the inhibitory effect of $\mathrm{Al}$ on growth was also found mainly in the elongation region, 1 to $6 \mathrm{~mm}$ from the root tip (Van et al., 1994). Peroxidase often acts to inhibit growth (Fry, 1986). However, Cateto 237, although it was the slowergrowing of the two inbred lines, had a lower overall level of peroxidase activity, and showed no change upon exposure to $\mathrm{Al}$.

Among the several genes that have been found to be up-regulated upon exposure to $\mathrm{Al}$ are a peroxidase from tobacco roots - al201 (Ezaki et al., 1996) and from wheat roots - war 4.2 (Hamel et al., 1998). However, transcripts of war 4.2 accumulated similarly among cultivars in response to Al toxicity, and were not implicated in the differential tolerance observed between cultivars. In our research, the ability of the tolerant inbred line to keep the peroxidase activity at constitutive levels under Al stress may be necessary for cell functioning. Ryan et al. (1993) showed that only the apical $2-3 \mathrm{~mm}$ of a maize root, which includes the meristem and root cap, needed to be exposed to $\mathrm{Al}$ to cause inhibition of root growth, suggesting that growth inhibition occurs through decreased cell division rather than through decreased cell expansion. Bennet et al. (1991) have suggested that the root cap is a site of perception of $\mathrm{Al}$ injury. In the sensitive inbred line, the apical $6 \mathrm{~mm}$ of root responded to $\mathrm{Al}$ exposure by reducing peroxidase activity, suggesting an attempt to maintain root growth rate. The short-term ( $80 \mathrm{~min}) \mathrm{Al}$ stress did not result in the expression of new peroxidase isoforms along the root apex for the two inbred lines (figures 4A and 4B).
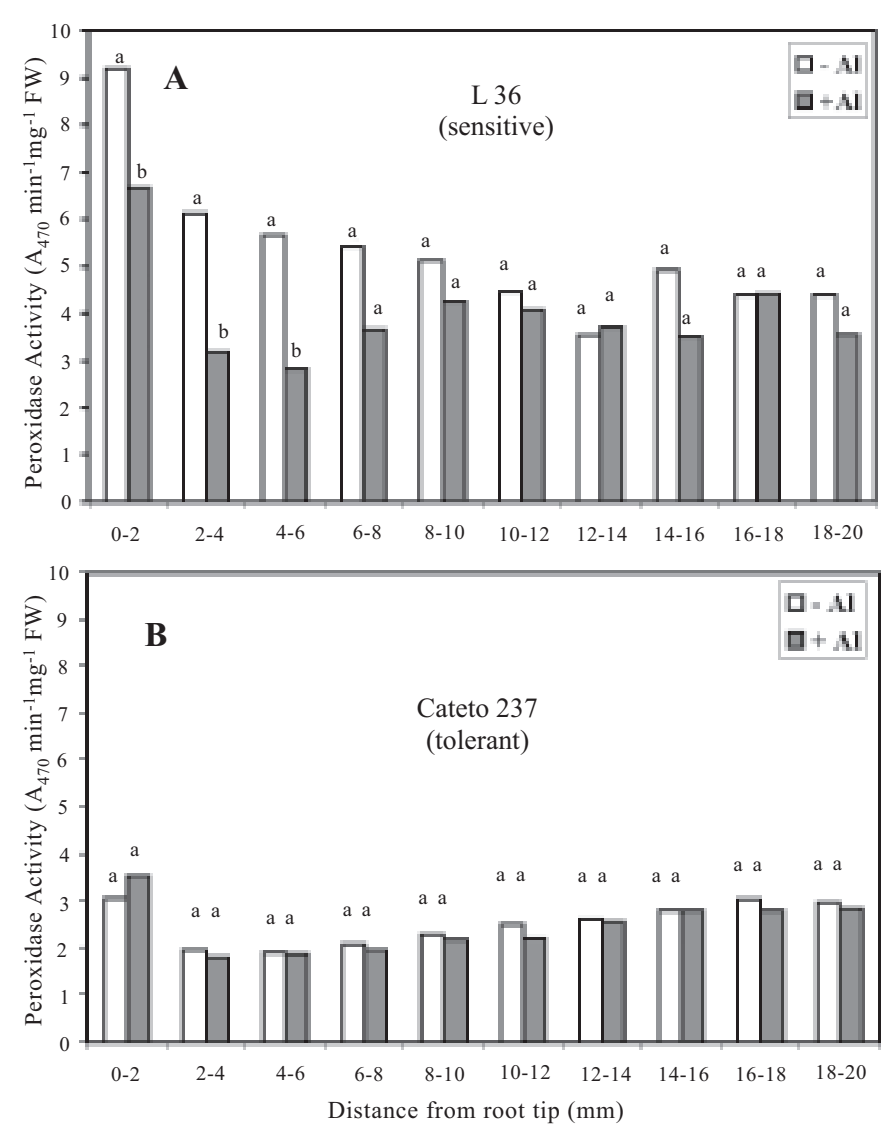

Figure 3. Peroxidase activity along the apical $20 \mathrm{~mm}$ of the main root of the inbred lines L36 (sensitive) and cateto 237 (tolerant) submitted to a short-term $(80 \mathrm{~min})$ without (-Al) or with $222 \mu \mathrm{M}$ aluminum stress (+Al). Bars, within the same region, followed by the same letter do not differ significantly according to Tukey's test at the probability level $\mathrm{P} \leq 0.05$ 
A

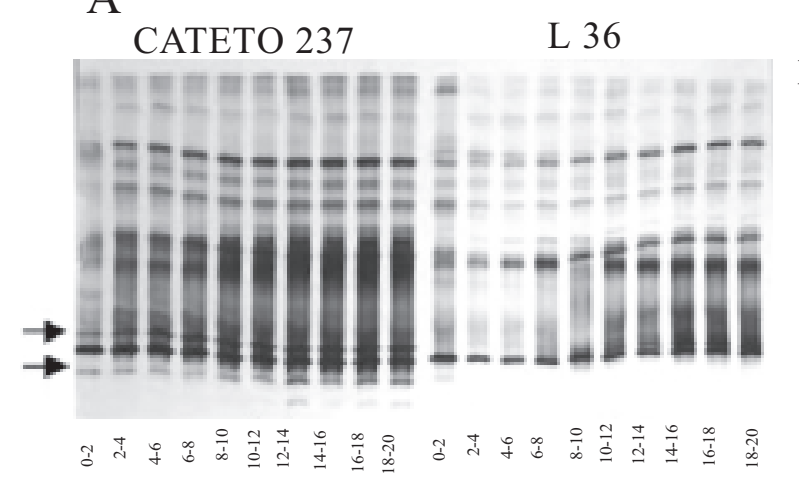

$\mathrm{B}$

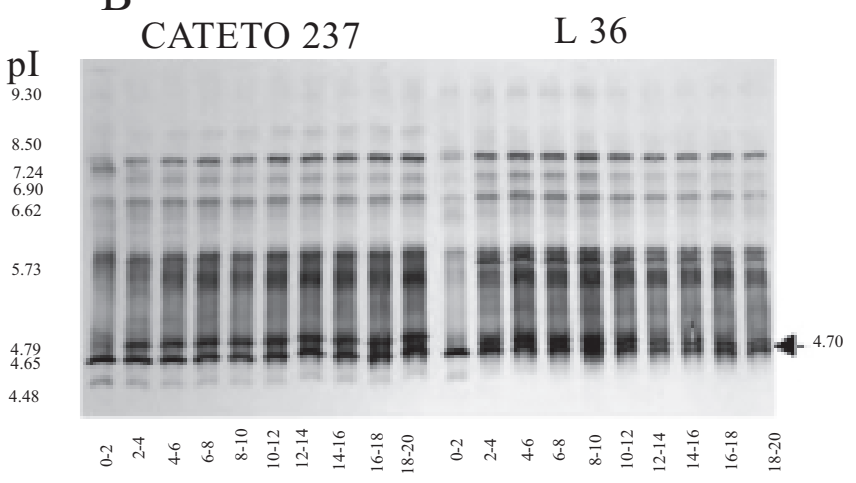

Distance from root tip $(\mathrm{mm})$

Figure 4. Zymograms of peroxidase along the apical $20 \mathrm{~mm}$ of the main root apex of the inbred lines L36 (sensitive) and cateto 237 (tolerant) submitted to a short-term (80 min) without (-Al) (A) or with $222 \mu \mathrm{M}$ aluminum stress (+Al) (B).

The major difference in the zymograms between the inbred lines was in the anionic isoforms: Cateto 237 constitutively expressed anionic peroxidases with $\mathrm{pI} 4.79$, 4.65, and 4.48, and L36 expressed anionic peroxidases isoforms with $\mathrm{pI} 4.65$ and 4.70 . Peroxidase activity has been suggested to modulate cell wall rigidity and extensibility (Fry, 1986). The slow growth of Cateto 237 could be related to the presence of more anionic isoforms, which are described to be associated with cell wall function in lignification and the cross-linking of extensins and feruloyated polysaccharides (Lamport, 1986). These results demonstrate that constitutive peroxidase activity levels are associated with the expression of more anionic isoforms, and increased protein expression may be an important component of the plant's reaction to Al toxicity.

\section{REFERENCES}

Bennet R J, Breen CM (1991) The aluminum signal: new dimensions to mechanisms of aluminum tolerance. Plant Soil 134:153-166.

Blum H, Beier H, Gross, HJ (1987) Improved silver staining of plant proteins, RNA and DNA in polyacrilamide gels. Electrophoresis 8:93-99.

Bradford MM (1976) A rapid and sensitive method for the quantitation of microgram quantities of protein utilizing the principle of protein-dye binding. Anal. Biochem. 72:248-254.

Bradley DJ, Kjellbom P, Lamb CJ (1992) Elicitor-and wound induced oxidative cross-linking of a proline-rich plant cell wall protein: A novel, rapid defense response. Cell 70:21-30.
Clark RB (1982) Plant response to mineral element toxicity and deficiency. In: Cristiansen MN, Lewis CF (eds), Breeding Plants for Less Favorable Environments, pp.71-142. John Wiley \& Sons, New York.

Ezakı B, Tsugita S, Matsumoto, H (1996) Expression of a moderately anionic peroxidase is induced by aluminum treatment in tobacco cells: possible involvement of peroxidase isoenzymes in aluminum ion stress. Physiol. Plant. 96:21-28.

Ezaki B, Gardner RC, Ezaki Y, Matsumoto H (2000) Expression of aluminum-induced genes in transgenic arabidopsis plants can ameliorate aluminium stress and/ or oxidative stress. Plant Physiol. 2000:657-665.

Foy CD (1988) Plant adaptation to acid, aluminum-toxic soils. Commun. Soil Sci. Plant Anal. 19:959-987.

Fry SC (1986) Cross-linking matrix polymers in the growing cell walls of angiosperms. Annu. Rev. Plant Physiol. 37:165-186.

Gaspar TH, Penel C, Greppin HA (1985) A two-step control of basic and acidic peroxidases and its significance for growth and development. Physiol. Plant. 64:418-423.

Hamel F, Breton C, Houde M (1998) Isolation and characterization of wheat aluminum-regulated genes: possible involvement of aluminum as a pathogenesis reponse elicitor. Planta 205:531-538.

Ho TH, Sachs MM (1989) Stress-induced proteins: Characterization and regulation of their synthesis. In: Marcus A (ed), The Biochemistry of Plants, pp.347378. Academic Press, San Diego.

Imberty AA, Goldberg R, Catesson A-M (1984) Tetramethylbenzidine and p-phenylenediamine-pyrocatechol for peroxidase histochemistry and biochemistry: two new, non-carcinogenic chromogens for investigating lignification process. Plant Sci. Lett. 35:103-108. 
Kochian LV (1995) Cellular mechanisms of aluminum toxicity and resistance in plants. Annu. Rev. Plant Physiol. Plant Mol. Biol. 46:237-260.

Laemmli UK (1970) Cleavage of structural proteins during the assemble of the bacteriophage T4. Nature 227:680-685.

Lamport DTA (1986) Roles for peroxidase in cell wall genesis. In: Greppin H, Penel C, Gaspar TH (eds), Molecular and Physiological Aspects of Plant Peroxidases, pp.199-208. University of Geneva Press, Geneva.

Magnavaca R (1982) Genetic variability and the inheritance of aluminum tolerance in maize (Zea mays L.). Lincoln, University of Nebraska. PhD thesis.

Picton SJ, Richards KD, Gardner RC (1991) Protein profiles in root-tips of two wheat (Triticum aestivum L.) cultivars with differential tolerance to aluminum.. In: Wright RJ, Baligar VC, Murrmann RP (eds), PlantSoil Interactions at Low pH, pp.1063-1070. Luwer Academic Publishers, Dordrecht, The Netherlands.

Rengel Z (1996) Uptake of aluminium by plant cells. New Phytol. 134:389-406.

Rincón M, Gonzales A (1991) Aluminum partitioning in intact roots of aluminum-tolerant and aluminum-sensitive wheat (Triticum aestivum L.) cultivars. Plant Physiol. 99:1021-1028.
Ryan PR, DiTomaso JM, Kochian LV (1993) Aluminium toxicity in roots: an investigation of spatial sensitivity and the role of the root cap. J. Exp. Bot. 44:437-446.

SAS Institute Inc. (1993) The GLM procedure in SAS Institute Inc., pp.891-996. SAS/STAT User's guide: Version 6.12. 4 ed. Carey, NC: SAS Institute Inc., Vol. 2, cap 24.

Sherf BA, Bajar AM, Kolattudkudy, PE (1993) Abolition of an inducible highly anionic peroxidase activity in transgenic tomato. Plant Physiol. 101:201-208.

Souza IRP, MacAdam JW (1998) A transient increase in apoplastic peroxidase activity precedes decrease in elongation rate of B73 maize (Zea mays L.) leaf blades. Physiol. Plant. 104:556-562.

Taylor GJ (1991) Current views of the aluminum stress response: the physiological basis of tolerance. In: Randall DD, Blevins DG, Miles CD (eds), Current Topics in Plant Biochemistry and Physiology, vol. 10, pp.57-93. University Missouri, Columbia.

Van L, Kuraishi S, Sakurai N (1994) Aluminum-induced rapid root inhibition and changes in cell-wall components of squash seedlings. Plant Physiol. 106:971-976.

Walter MH (1992) Regulation of lignification in defense. In: Boller, Meins F. (eds), Genes Involved in Plant Defense, pp.327-352. Spring-Verlag, Wien, New York. 